\title{
Stamceller i lungekreft
}

\section{Selv om mange i den vestlige verden har sluttet å røyke, er fortsatt lungekreft årsaken til de fleste kreftdødsfall globalt.}

Moderne behandling av lungekreft er multimodal og består av kirurgi, strålebehandling og cellegift. På tross av dette er bare $10 \%$ av norske pasienter med lungekreft i live fem år etter behandlingen.

Det er i dag vist at det finnes normale stamceller i de fleste organer. Stamceller karakteriseres ved at de har evne til selvfornyelse og gir opphav til differensierte organspesifikke celler. I de senere årene er det postulert at det også finnes tumorstamceller i flere kreftformer og at disse, som representerer en liten subpopulasjon av kreftcellene, kan initiere tilbakefall av sykdommen etter primærbehandlingen.

- Lungekreft er generelt svært resistent mot cellegift. Årsaken til dette er ikke helt klarlagt. Tilstedeværelse av tumorstamceller i lungekreft kan forklare hvorfor denne kreftformen er så terapiresistent, sier Ping Wang.

De fleste studier på lungekreftstamceller har vært utført på veletablerte cellelinjer eller på tumorvev.

- Vi utviklet en metode for å dyrke lunge- kreftceller fra ferskt lungesvulstvev. Metoden, som er svært reproduserbar, har vist at man kan etablere primærlungekreftcellelinjer fra alle typer av lungekreft. Da vi studerte disse cellelinjene videre, påviste vi at en liten subpopulasjon av lungekreftcellene hadde karakteristika som stamceller. Interaksjon mellom stamceller og mikromiljøet som de lever $i$, regulerer når og hvordan stamceller deler seg. Ved å bruke de nyetablerte lungekreftcellelinjene studerte vi også mikromiljøets betydning for hvordan cellene får karakter som tumorstamceller, forteller Wang.

Konklusjonen tyder på at mikromiljøet er avgjørende for hvordan tumorceller utvikler karakteristika som tumorstamceller. Kunnskapen vil være av betydning for hvordan man kan utvikle ny og mer effektiv behandling for lungekreft.

\section{Tone Bergset}

tone.bergset@legeforeningen.no

Tidsskriftet

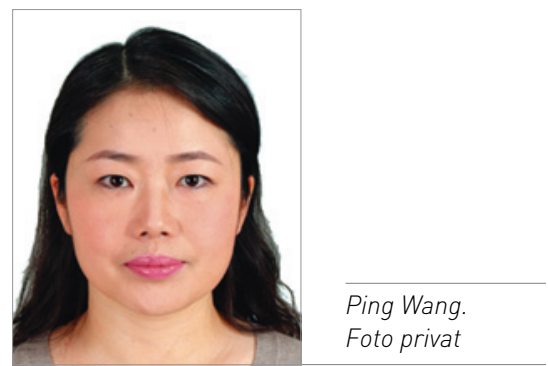

\section{Disputas \\ Ping Wang disputerte for ph.d.-graden ved Universitetet i Oslo 5.4. 2013. Tittelen på avhandlingen er Cancer stem cells in lung cancer: isolation, identification and biological properties.}

\section{Dosering av aminoglykosid ved febril nøytropeni}

\author{
Én enkelt døgndose tobramycin gir like god effekt som tredelt dosering \\ av midlet i behandling av febril nøytropeni hos pasienter med kreft.
}

I Norge behandles pasienter med febril nøytropeni empirisk med aminoglykosid dosert tre ganger i døgnet, i kombinasjon med penicillin. Lege og forsker Dag Torfoss har i sitt doktorgradsarbeid oppsummert studiene omkring dette behandlingsregimet ved feber etter cellegiftbehandling. Sju studier, alle norske, finnes på området. Alle viser at penicillin og aminoglykosid er effektiv og sikker initial behandling til denne pasientgruppen, forutsatt at antibiotikaregimet modifiseres hvis den kliniske tilstanden ikke er tilfredsstillende.

Hovedarbeidet $\mathrm{i}$ avhandlingen var en prospektiv randomisert klinisk studie hvor 174 voksne pasienter med febril nøytropeni ble inkludert. De ble enten behandlet med det tradisjonelle regimet med tre doser tobramycin $i$ døgnet eller med én dose tobramycin i døgnet, begge i kombinasjon med penicillin. Pasientene ble fulgt i 30 dager etter behandlingsstart. Ingen var i septisk sjokk da behandlingen ble igangsatt.

- Studien viste at tobramycin gitt én gang $\mathrm{i}$ døgnet var like effektivt som det tradisjonelle regimet med tredelt dosering, sier Torfoss.

I begge gruppene var det $40 \%$ av pasientene som ikke fikk endret antibiotikaregimet $\mathrm{i}$ forløpet av episoden med febril nøytropeni. Kreatininstigningen var svært moderat og lik i begge grupper. Ingen pasienter døde i forløpet av febril nøytropeni. Nøytropenien varte gjennomsnittlig i ni dager i begge grupper.

- Denne studien viser at et forenklet behandlingsregime med penicillin og aminoglykosid, med færre doseringer og prøvetakinger av aminoglykosidkonsentrasjoner, gir like god effekt som det tradisjonelle behandlingsregimet. Det er også god grunn til å anta at penicillin og aminoglykosid gir mindre resistens enn bredspektrede $\beta$-laktamantibiotika, som er vanlig å gi i utlandet, avslutter Torfoss.

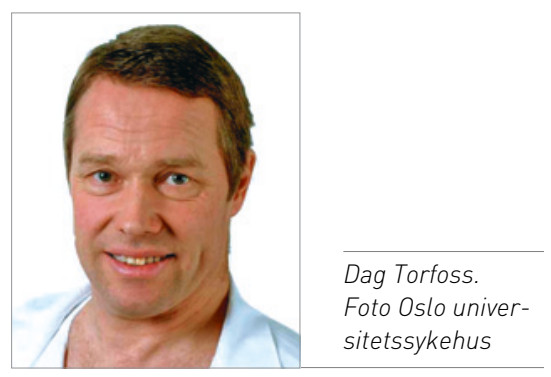

Disputas

Dag Torfoss disputerte for ph.d.-graden ved Universitetet i Oslo 21.3. 2013. Tittelen på avhandlingen er Penicillin $G$ plus an aminoglycoside in febrile neutropenia. 